\title{
The endoplasmic reticulum chaperone GRP170: from immunobiology to cancer therapeutics
}

\author{
Hongxia Wang ${ }^{1 \neq}$, Abdul Mohammad Pezeshki ${ }^{1+\neq}$, Xiaofei Yu ${ }^{1}$, Chunqing Guo ${ }^{1}$, John R. Subjeck ${ }^{3 *}$ and \\ Xiang-Yang Wang ${ }^{1,2,4}$ *
}

1 Department of Human Molecular Genetics, Virginia Commonwealth University, Richmond, VA, USA

${ }^{2}$ Massey Cancer Center, Virginia Commonwealth University, Richmond, VA, USA

${ }^{3}$ Department of Cell Stress Biology, Roswell Park Cancer Institute, Buffalo, NY, USA

${ }^{4}$ Institute of Molecular Medicine, Virginia Commonwealth University, Richmond, VA, USA

\section{Edited by:}

Paul Eggleton, Exeter University Medical School, UK

Reviewed by:

Subramaniam Malarkannan, Medical College of Wisconsin, USA

Behjatolah Monzavi-Karbassi,

University of Arkansas for Medical

Sciences, USA

${ }^{*}$ Correspondence:

John R. Subjeck, Department of Cellular Stress Biology, Roswell Park

Cancer Institute, Buffalo, NY 14221,

USA

e-mail: john.subjeck@roswellpark.org;

Xiang-Yang Wang, Department of

Human and Molecular Genetics,

Virginia Commonwealth University,

Richmond, VA 23298, USA

e-mail: xywang@vcu.edu

\section{${ }^{\dagger}$ Present address:}

Abdul Mohammad Pezeshki,

Department of Immunology, Mayo

Clinic, Rochester, MN, USA

${ }^{\ddagger}$ Hongxia Wang and Abdul

Mohammad Pezeshki have

contributed equally to this work.
Glucose-regulated protein 170 (GRP170) is the largest member of glucose-regulated protein family that resides in the endoplasmic reticulum (ER). As a component of the ER chaperone network, GRP170 assists in protein folding, assembly, and transportation of secretory or transmembrane proteins. The well documented cytoprotective activity of intracellular GRP170 due to its intrinsic chaperoning property has been shown to provide a survival benefit in cancer cells during tumor progression or metastasis. Accumulating evidence shows that extracellular GRP170 displays a superior capacity in delivering tumor antigens to specialized antigen-presenting cells for cross-presentation, resulting in generation of an anti-tumor immune response dependent on cytotoxic $\mathrm{CD}^{+} \mathrm{T}$ cells. This unique feature of GRP170 provides a molecular basis for using GRP170 as an immunostimulatory adjuvant to develop a recombinant vaccine for therapeutic immunization against cancers. This review summarizes the latest findings in understanding the biological effects of GRP170 on cell functions and tumor progression. The immunomodulating activities of GRP170 during interactions with the innate and adaptive arms of the immune system as well as its therapeutic applications in cancer immunotherapy will be discussed.

Keywords: endoplasmic reticulum, glucose-regulated protein 170, molecular chaperone, anti-tumor immunity, cancer vaccine

\section{INTRODUCTION}

The endoplasmic reticulum (ER) is the key organelle that plays a critical role in many cellular processes, including protein synthesis, post-translational modification, and proper folding (1). Molecular chaperones in the ER lumen, through non-covalent interactions with their client proteins, catalyze or regulate protein folding, complex formation, protein translocation, or degradation (2-6). The physiological and pathological stress conditions that disturb the highly oxidizing and calcium-rich ER environment can trigger unfolded protein response (UPR) $(7,8)$. The UPR is a protein quality control mechanism that aims to limit ER stress and restore ER homeostasis, in part by inducing the elevation of ER chaperones, which enhance the protein folding/refolding capacity of the ER and target misfolded proteins to the ER-associated degradation (ERAD) pathway for degradation $(9,10)$.

Glucose-regulated proteins (GRPs) are among the most abundant and well-characterized ER chaperones (10). As stressinducible chaperones, GRPs were originally discovered in mammalian cells undergoing glucose deprivation (11-13). GRPs are functionally and structurally related to the heat shock proteins
(HSPs) and belong to the HSP family (14-16). Unlike most of the HSPs that reside mainly in the cytosol and the nucleus, the GRPs are predominantly in the ER $(15,16)$. Major members of the GRP family include GRP78/Bip, GRP94/Gp96, and GRP170 [also known as oxygen-regulated protein (ORP) 150 and HYOU1] (15, 16). These GRPs are often induced by stressors that perturb the ER functions, e.g., hypoxia, nutrient deprivation, reducing agents, calcium depletion, low $\mathrm{PH}$, hyper-proliferation, or viral infection $(16,17)$. Due to their cytoprotective and pro-survival activities (18-21), GRPs have been extensively studied in the context of cancer development and progression, including cellular signaling, proliferation, apoptosis, angiogenesis, metastasis, and resistance to therapeutics $(10,15,22,23)$. To target the autonomous tumorpromoting effect of intracellular GRPs, many approaches or agents are being developed and tested for their anticancer efficacy in the experimental models and in the clinic (15). Over the last two decades, a wealth of studies has demonstrated novel aspects of GRP functions, intracellularly or extracelluarly, in regulating innate and adaptive immune responses during interactions with the host immune system. This has provided new opportunities to develop 
immune-based strategies for cancer treatment (16,24-26). As the largest GRP and molecular chaperone in the ER, GRP170 has been less studied compared to other members in the same class. In this review, we highlight recent progress in chaperoning-based diverse activity of GRP170, and discuss the potential applications of exploiting the immunological features of this molecule to design novel anticancer therapeutics.

\section{Grp170 AND ITS CHAPERONING PROPERTY}

Grp170 was initially found in the early 1980s during a study of GRP induction by glucose starvation (13). More than 10 years later, we cloned the cDNA of mammalian GRP170 from Chinese Hamster Ovary cells (27). GRP170 has also been referred to as ORP 150 (28), which indeed is the unglycosylated form of GRP170 (28). Sequence analysis indicated that GRP170 represents a new stress protein family that is distantly related to, but different from, both HSP70 and HSP110 families (27). The HSP70, HSP110, and GRP170 families have been classified into the "HSP70 Super-Family" $(14,29)$. GRP170 consists of 999 amino acids, encoded by hypoxia upregulated 1 gene (Hyoul) that is located on the q arm of chromosome 11. Beside glucose starvation as a classical inducer of GRPs, including GRP170, other stressors, such as hypoxia, ischemia, perturbation of calcium homeostasis, proteasome inhibitors, and non-steroidal anti-inflammatory drugs (e.g., celecoxib) are also known to upregulate GRP170 expression (13, 30-36).

Predicted secondary structural modeling indicated that the overall organization of GRP170 is similar to that of HSP70 and HSP110, but with very little similarity in C-terminal regions (14, $27,29,37)$. GRP170 also has a high degree of homology to GRP78, the ER homolog of HSP70, as they all possess an N-terminal nucleotide binding domain (NBD) followed by a $\beta$-sheet domain, which acts as the substrate binding domain (SBD) and an $\alpha$ helical domain at the $\mathrm{C}$ terminus. The increased size of GRP170 is due to the insertion of an acidic loop in their $\beta$-sheet domain and an extended $\mathrm{C}$ terminus following the $\alpha$-helical domain (14, 38). It has long been known that GRP170 associates with the other major GRPs (e.g., GRP78) in the ER and interacts with immunoglobulin chains $(39,40)$, implicating its role in protein folding or assembly in concert with other GRP or ER chaperones. GRP170 was shown to be the most efficient ATP-binding protein in microsomal extract, and was suggested to assist the translocation of polypeptides into the ER via the transporter associated with antigen processing (TAP) $(41,42)$. The yeast counterpart of GRP170 (Lhs1; lumenal HSP70) displayed similar activity in transporting proteins into the $\operatorname{ER}(29,43,44)$. Biochemical studies demonstrate that GRP170 is significantly more effective in blocking heat-induced protein aggregation than other stress proteins or chaperones $(37,45-48)$, underscoring a superior chaperoning capacity of this only ER member of the large HSP70 family.

Protein folding mediated by the GRP78-centered chaperoning machinery in the ER is regulated by its bound nucleotide, i.e., cycling of ATP and ADP (49). ADP-bound GRP78 has a high affinity for unfolded or incompletely folded proteins, while exchange of ADP for ATP decreases the affinity of GRP78 for substrates lead to release of folded protein substrate $(49,50)$. Surprisingly, Grp170 was recently reported to function as a nucleotide exchange factor (NEF) for GRP78 in the ER (50-52), which also raised the question of GRP170 being an independent chaperone molecule. A recent study confirmed that Grp170 can directly bind to a variety of incompletely folded protein substrates in vivo, although the regulation of its substrate binding function is different than for conventional HSP70 (53). GRP170 and GRP78 can associate with similar molecular forms of two substrate proteins. However, while GRP78 is released from unfolded substrates in the presence of ATP, GRP170 remains bound (53), suggesting that binding of same substrate to different GRPs may result in distinct fates for their client proteins. These data further established the GRP170 as a bona fide chaperone. More studies are necessary to address the question as to why GRP170 in the ER possess the dual ability to bind to substrates or client proteins and to have NEF activity (54).

\section{ER STRESS AND GRP170-CONFERRED CYTOPROTECTION}

In addition to playing important roles in protein modification and folding, the ER as a major organelle also integrates and coordinates cellular responses to a variety of stressors $(55,56)$. Disturbance of the ER functions by inhibiting protein glycosylation or disrupting calcium homeostasis, oxidative stress, pathogen infection, can result in the accumulation of unfolded or misfolded proteins in the ER that will trigger the UPR. The induction of GRPs and ERresident chaperone molecules, including GRP170, often used as an indicator of the UPR, can help overcome the excessive protein loading and maintain or recover ER functions $(7,57)$.

There are three major signaling pathways involved in the canonical UPR upon ER stress, which includes pancreatic ER kinase (PERK), inositol-requiring transmembrane kinase/endonuclease1 (IRE-1), and activating transcription factor-6 (ATF6) $(7,58)$. These ER stress sensors upon activation will initiate a cascade of molecular events that help diminish the protein load by inhibiting protein translation or by limiting the pool of mRNAs available to enter the ER. They can concurrently engage a transcriptional program to upregulate a number of genes, e.g., ER chaperones including GRPs, X-box binding protein 1 (XBP-1), and ERAD components, which are crucial for protein folding, amino acid metabolism, and protein degradation (7, 59-61). Activated ATF6 transported to the nucleus induces the transcription of the GRPs mRNA by binding to the ER stress response element (ERSE) in their genes (58). Activated PERK phosphorylates eukaryotic initiation factor $2 \alpha(\mathrm{eIF} 2 \alpha)$, resulting in translation of the ATF4, which also binds to the ERSE sequence to increase the expression GRPs (58). Both ATF6 and ATF4 have been reported to mediate the UPRdependent induction of GRP170 due to the existence of ERSE in its gene $(30,31,62,63)$. The IRE1 $\alpha$ induces the unconventional splicing of XBP-1 mRNA and production of the longer isoform of spliced XBP-1 (XBP-1s), which stimulates the transcription of ER chaperone genes, including GRP170 $(58,64,65)$.

Several lines of evidences support a cytoprotective role of intracellular GRP170 in response to ER stress. GRP170 can limit oxidized low density lipoprotein (ox-LDL)-induced ER stress and prevent subsequent cell apoptosis $(66,67)$. GRP170 executes this protective activity by maintaining calcium homeostasis and blocking calcium signaling through IP3 channels (67). Cytoprotection conferred by induction of GRP170 has also been shown in cellular responses to other ER stressors, e.g., proteasome inhibitors that cause excessive protein accumulation $(30,68)$, hypoxia, 
ischemia-reperfusion (69-72), and glutamate-induced cytotoxicity (73). However, the conventional UPR signaling is not the only molecular mechanism involved in the induction of GRP170. In a high fat diet-fed mouse model, AMP-activated protein kinase (AMPK) was reported to mediate the elevation of GRP170, which ameliorated hepatic ER stress and lipotoxic death. Forkhead box O1 (FOXO1), which can directly bind to the promoter region of GRP170 gene, was identified as the critical transcription factor mediating the AMPK-enhanced GRP170 expression at both the mRNA and protein levels in hepatocytes (74). However, an animal study of COX-2 inhibitor (i.e., parecoxib)-mediated neuroprotection from cerebral ischemic reperfusion injury showed that the elevation of GRP170 was observed in the presence of suppression of FOXO1 activation (75). GRP170 was found to directly bind to ER stress sensors, such as PERK, ATF6, and IRE1 $\alpha$ in vascular cells (66) or PERK and eIF2 $\alpha$ in hepatocytes (74), which suggests that the ER-resident GRP170 may be able to retain those ER stressors inside of ER and maintain them in an inactive state, thereby preventing the activation of ER stress.

\section{GRP170 IN CANCER DEVELOPMENT AND PROGRESSION}

Tumor development is associated with cell hyper-proliferation, protein overexpression, and emergence and accumulation of mutated or misfolded oncogenic proteins, which often induce overexpression of GRPs and other ER chaperone molecules in cancer cells $(10,15,76)$. Elevation of chaperone molecules may be required for the maintenance of the functions of those proteins essential for tumorigenesis or invasion. The deprivation of glucose and hypoxic condition in the tumor microenvironment, caused by poor vascularization in most of the neoplastic tumors, can act as ER stressors that activate the UPR in cancer cells to promote their survival (77-79). It has been well documented that many ER chaperones, including GRP78, GRP94, and calreticulin (CRT), are capable of protecting cancer cells against ER stress-induced cell death (76, 80-84). Upregulation of GRP78 (85-88) and GRP94 (89-91), likely due to the adaptive UPR in cancer cells, have also been associated with the poor survival or recurrence in cancer patients as well as tumor resistance to radiotherapy.

The levels of GRP170 were also shown to correlate with cancer invasiveness and GRP170 was suggested to be a potential prognostic factor in human breast cancer (92). In addition to altered expression of GRP170 in the different stage of breast cancer, the upregulation of GRP170 correlated with tumor lymph node invasion and decreased expression of estrogen receptor (93), implicating its potential involvement in cancer metastasis. Beside cytoprotection or resistance to cell death conferred by GRP170, other activities of GRP170 during tumor progression have been elucidated. Angiogenesis, formation of new capillaries from preexisting vessels, is an important process in tumor growth and metastasis. GRP170 was shown to be required for the angiogenesis of $\mathrm{C} 6$ glioma tumors by facilitating the processing and secretion of vascular endothelial growth factor (VEGF), a major proangiogenic factor (94). Similarly, suppression of GRP170 using an antisense approach reduced the tumorigenicity of human prostate cancer cells through blocking of secretion of matured VEGF (95). GRP170 in bladder cancer cells was also found to chaperone matrix metalloproteinase-2 (MMP-2) for secretion, thereby promoting tumor invasion (96). While additional studies are needed to better understand the precise contribution of GRP170 in tumorigenesis, the chaperoning property appears to be a main underlying mechanism involved in its pro-tumor activity (Figure 1). Interestingly, it was recently found that ER-stressed tumors could propagate the stress signals to the neighboring cells (e.g., macrophages) via secretion of soluble mediators, which lead to an amplified inflammatory response that facilitates tumor progression $(10,97)$. It is not clear as to whether GRPs or ER chaperones in cancer cells contribute to this pro-inflammatory and pro-tumoral effect.

\section{CANCER IMMUNOGENICITY ALTERED BY COMPARTMENTALIZATION OF GRP170}

Glucose-regulated proteins or ER chaperones are initially considered to be exclusively intracellular proteins that only released into extracellular environment upon cell injury (98). GRP170, like other GRPs, resides normally in the lumen of ER due to an ER-retention signal, KNDEL, at its carboxyl terminus. However, it is now apparent that ER chaperones can be present on the plasma membrane or actively secreted into the extracellular environment $(10,99-101)$. The differential localizations of GRPs could potentially have distinct impact on cellular activities and the host response. The cell surface GRP78 acts as a multifunctional receptor that promotes cancer cell survival and proliferation by activating ERK and AKT $(102,103)$, PI3k (104), or NF- KB and AKT (105). In contrast, tumor cells forced to secrete GRP78 resulted in a tumor-reactive immune response and tumor rejection (106). Another ER chaperone CRT was recently reported to translocation to the tumor cell surface upon exposure to chemotherapeutic agents or ionizing irradiation $(107,108)$. The surface CRT serves as an "eat me" signal that triggers increased phagocytosis of dying tumor cells, cross-presentation of tumor antigens, and consequent anti-tumor immune response (109).

We have performed studies to determine the impact of extracellular secretion of GRP170 on tumorigenicity. In this regard, murine B16 melanoma cells (47), TRAMP-C2 prostate cancer cells (110), or CT26 colorectal cancer cells (111) were forced to express a secretable form of GRP170, in which its ER-retention sequence "KNDEL" has been depleted. We found that these cancer cells secreting GRP170 did not differ from their mock-treated controls in cell proliferation in vitro. However, the tumor growth was markedly suppressed in vivo, which was dependent on the presence of cytotoxic $\mathrm{CD} 8^{+} \mathrm{T}$ lymphocytes (CTLs) and/or natural killer (NK) cells. This secretory GRP170 not only acted as a "danger" signal stimulating specialized antigen-presenting cells (APCs), such as dendritic cells (DCs), but also delivered tumorderived antigens via its intrinsic chaperoning activity for priming antigen-specific CTLs (47). Using mass spectrometry analysis, we demonstrated that this secreted GRP170 was associated with tumor protein antigens (111), which is consistent with the intracellular chaperoning function of GRPs or ER chaperones that are essential for the activity of oncoproteins in cancer cells.

The studies of cell surface GRP94 (112) or GRP94 secreted from tumor cells (113-115) support our findings by demonstrating that the exposure of GRP94 to the immune system represents a highly 


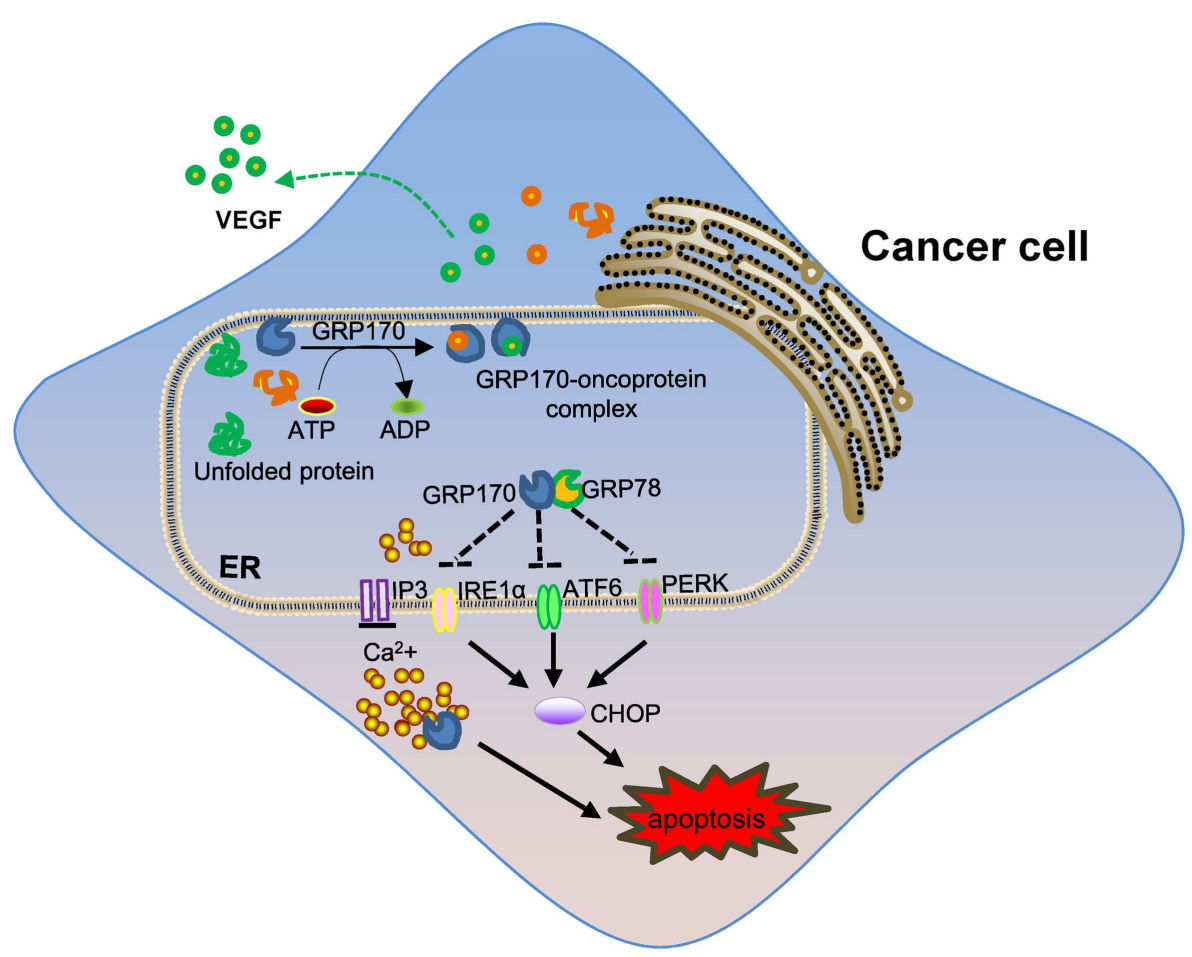

FIGURE 1 |The role of intracellular GRP170 in tumor development. ER-resident GRP170 together with other GRPs (e.g., GRP78) or chaperone molecules participate in post-translational modification and protein folding or transportation. Under stress conditions (e.g., ER stress), GRP170 exhibits cytoprotective activity by preventing protein aggregation or help protein repair and maintaining calcium homeostasis in the ER. GRP170 can directly bind to and possibly keep the ER stress sensors (e.g., PERK, ATF6, and IRE1 $\alpha$ ) in quiescent inactivate state to limit ER stress. The pro-survival effect of intracellular GRP170 and chaperoning of oncogenic or tumor-promoting factors (e.g., VEGF) may contribute to tumor progression and invasion. immunogenic signal capable of inducing a potent anti-tumor immune response. Further support came from a study showing that enforced cell surface expression of GRP94 in a transgenic mouse conferred hyper-responsiveness to LPS and induced lupuslike autoimmune syndrome $(116,117)$. Thus, GRP170 or other ER chaperones may display dual biological or immunological activities during tumor progression or in response to therapeutic treatments, which depends on individual GRPs as well as their cellular compartmentalization. Intracellular or ER-resident GRPs play a general protective role that promotes the survival of cancer cells in stress or lethal conditions. However, the membrane-bound or extracellular GRPs could alter the immunogenicity of cancer cells and facilitate the immune recognition as well as immune-mediated destruction of cancers $(10,15,16,118-120)$. Manipulating cellular compartmentalization of GRP170 may be used to induce or restore protective anti-tumor immunity for cancer eradication. Genetically modified cancer cells with a capacity to produce secretory GRP170 have been successfully tested as a cell-based vaccine to generate a therapeutic anti-tumor response to the established tumors in mice $(47,110)$. We also demonstrated that intratumoral delivery of secretory GRP170 via an adenovirus promoted the anti-tumor efficacy of melanoma differentiation-associated gene7 (mda-7), a cancer-specific therapeutic cytokine, by mounting systemic anti-tumor immunity that controls treated as well as distant untreated tumor lesions (121).

\section{GRP170 AS AN IMMUNE ADJUVANT OF CANCER VACCINE}

Glucose-regulated protein preparations or ER chaperones-derived from tumors are believed to carry individually distinct array of tumor antigens, which can be utilized to provoke a tumor-specific immune response in cancer vaccination or immunotherapy (25, 122-128). Our early studies showed that animals immunized with GRP170 purified from various murine tumors (e.g., colon tumor, melanoma, and fibrosarcoma) developed a robust anti-tumor immune response $(126,129)$. Tumor-derived GRP170, when compared to other chaperones, displayed a higher anti-tumor potency (129), which, we believe, is attributed to its superior protein or antigen-holding capacity (48). The substantially increased size of GRP170 due to the extension of its C-terminal domain could be a factor, which enables it to bind to and chaperone protein clients or antigens more efficiently $(14,16)$. Indeed, two independent regions in GRP170, i.e., the classical peptide-binding $\beta$-sheet domain and the $\mathrm{C}$-terminal $\alpha$-helix domain, have been identified that can execute chaperoning activities (37).

To overcome the hurdle of preparing autologous GRP vaccines for clinical use, which can be limited by a requirement of patient specimen and laborious procedures of vaccine production $(130,131)$, we have developed a recombinant chaperoning technology that exploits the exceptional antigen-holding capacity of GRP170 (132). The reconstituted chaperone complex of GRP170 and melanoma-associated antigen gp100 has been used 
as a targeted vaccine to generate a strong anti-tumor immune response to aggressive, poorly immunogenic B16 melanoma in mice (132). Similar observations have been made in other vaccination studies that employed GRP170 to target different tumor antigens $(133,134)$. This recombinant vaccine approach has several advantages over autologous vaccines. The GRP170-antigen complex vaccine can be prepared in large quantities for use off-theshelf. A large reservoir of antigenic epitopes in a protein antigen can stimulate polyepitope-directed $\mathrm{T}$ cells and potentially enhance the strength of the anti-tumor effect. Our recent comparison study of GRP170-protein antigen complex vs. GRP170-peptide antigen in the setting of therapeutic immunization against cancer strongly supports the idea of including protein antigen in this vaccine regimen (48). Use of defined antigenic target should also facilitate the monitoring of antigen-specific immune responses in the clinic. Additionally, the highly efficient antigen-holding property will permit the development of a multivalent vaccine against different antigenic targets (48).

\section{EXTRACELLULAR GRP170 AND ANTIGEN CROSS-PRESENTATION}

Dendritic cells are one of most efficient APCs for processing and presenting antigens to T lymphocytes. Cross-priming of the CD8 ${ }^{+}$ $\mathrm{T}$ cells by DCs plays a crucial role in the induction of antiviral and anti-tumor immune responses. The cross-presentation efficacy of DCs is determined by many factors, including their ability to capture antigens, the route of antigen uptake and trafficking, antigen stability, and the pathways by which processed antigen is loaded on the MHC class I molecules. Generally, two models have been proposed for antigen cross-presentation, i.e., the vacuolar pathway and the cytosolic pathway $(135,136)$. In the vacuolar pathway, internalized antigens remain in endolysosomal/phagosomal compartments, where they are degraded and loaded onto the recycling MHC class I molecules (137-139). In the cytosolic pathway, the endocytosed antigens are transported from endosomes or phagosomes into the cytosol for proteasomedependent degradation, followed by peptide import and loading onto MHC class I molecules in the ER (140-143).

The choice of adjuvant is critical in the success of antigentargeted, protein-based cancer vaccines because soluble protein antigens are typically poorly cross-presented by DCs. One of major tenets in the vaccine activity of GRPs and other chaperone molecules, including GRP170, is their high efficiency to introduce antigens into the endogenous antigen-processing pathway of APCs for cross-presentation and activation of CTLs (48, 132, 144-147). The interaction of intracellular GRP170 with TAP in the early studies suggested that endogenous GRP170 may assist with ER translocation of peptides $(41,42)$. Two scavenger receptors, SR$A$ and SREC-I, have been identified to contribute to the binding of GRP170 on APCs (148). However, the mechanism of crosspresentation enhanced by exogenously delivered GRP170 in the context of tumor vaccination is poorly defined.

Using a clinically relevant melanoma antigen gp100 carried by GRP170, we recently investigated the trafficking pathways of GRP170-gp100 complex in DCs. Surprisingly, we found that the GRP170 directed and enhanced gp100 efficiently to access the ER after their internalization. GRP170-facilitated gp100 processing and presentation was dependent on the ERAD machinery involving Sec61, which was shown to target gp100 for ubiquitination and degradation in the cytosol by the proteasome system and subsequent integration into the conventional MHC class I restricted antigen-processing pathway (149). Our data indicated that GRP170 can help the associated protein antigen escape from lysosomal degradation and shuttle the antigen into the ER compartment from the early endosomal compartment. Internalized GRP170 might be directly involved in the ERAD following vaccine uptake, because GRP170 in the complex enhanced the interaction of gp100 with several ERAD molecules (e.g., Sec61 $\alpha, \mathrm{VCP} / 97$, CHIP, and GRP78). We speculate that gp100 protein that is partially unfolded during the vaccine preparation and chaperoned by GRP170 serves as an ERAD target once accessing the ER. Since endogenous GRP170 also binds to Sec61 $\alpha$, it is likely that internalized GRP170 could become a part of the ER chaperone network and collaborate with other GRPs to guide retrotranslocation of gp100. The GRP170/Lhs in yeast was recently reported to facilitate the ERAD of the epithelial sodium channel by preferentially targeting the unglycosylated form of the protein, which relied on its holding function not NEF activity (150). In our studies, the transient co-localization of ER markers with early endosome marker suggested an interesting possibility of formation of ER/endosome fusion structure after vaccine captured by DCs, which may explain the route of the ER access of GRP170-gp100 complex from the extracellular environment. Intriguingly, the GRP170-peptide antigen complex was recently found to be transported into early and recycling endosome compartments, where antigen was processed (151). It appears that the distinct trafficking patterns are caused by the size or nature of the antigens (protein vs. peptide) chaperoned by GRP170 in vaccines.

ER-associated degradation is an essential protein quality control mechanism in the ER that retrotranslocates unfolded or misfolded proteins to cytosol for degradation in response to ER stress $(152,153)$. ERAD involving Sec61 and chaperone molecules have been implicated in the cytosolic pathway of antigen cross-presentation $(137,154)$. Several lines of evidence suggest that the ERAD components are present on or can be recruited to the endosome/phagosome in APCs to facilitate cytosolic translocation of antigen (155-158). However, ER access and ERAD-mediated processing of GRP170-antigen complex in the setting of therapeutic vaccination warrant more studies, which will result in a better understanding of the action of this molecular adjuvant and the optimization of GRP170-based targeted cancer vaccination strategies.

\section{EXTRACELLULAR GRP170 AS AN ALARMIN AND INNATE IMMUNITY}

Upon release from injured or stressed cells, certain chaperone molecules, including GRPs, are suggested to serve as alarmins or damage-associated molecular patterns to alert the host immune systems of cell or tissue stress and trauma $(159,160)$. It has been well established that GRP170-dependent tumor immunization offers effective treatment of malignancies in the experimental models. The acquired immunity enhanced by GRP170 through shuttling and presenting tumor antigens for T cell cross-priming is an essential component of this process. The previous studies 
showed that GRP170 bound to DCs in a receptor-mediated fashion (i.e., scavenger receptors SR-A and SREC-I) (148) and GRP170 by itself could modestly induce DCs to upregulate MHC class II and co-stimulatory molecules (e.g., CD86) (120). Binding of GRP170 to DCs also stimulated them to produce proinflammatory cytokines (120). Although this stimulatory effect appears to be modest, it distinguishes GRP170 or other GRPs from other conventional adjuvants in vaccine design and formulation.

Vaccine adjuvants can be functionally divided into two major groups, toll-like receptor (TLR)-dependent and TLR-independent adjuvants $(161,162)$. TLR-dependent adjuvants, such as the Bacillus Calmette-Guerin (BCG) that is recognized by TLR2 and TLR4, act directly on DCs and promote their maturation and migration to the $\mathrm{T}$ cell area of the lymph node $(161,162)$. TLR-independent adjuvants, e.g., alum, increase antigen availability at injection site by adsorption and entrapment of antigens $(163,164)$. GRP170 along with other chaperone molecules, as self-proteins of mammalian origin, may be considered as the third functional group of adjuvants, because they increase the immunogenicity of antigens via preferentially delivering antigen cargos to DCs and enhancing antigen cross-presentation by DCs (120, 132, 148, 149, 165).

In addition to chaperoning intracellular antigenic polypeptides, GRP170 can efficiently bind to foreign pathogen-associated molecular patterns (PAMPs) in the extracellular environment and enhance the host response to pathogens. We recently showed that GRP170 interacts with microbial DNA, e.g., CpG oligodeoxynucleotides (CpG-ODN), a ligand for TLR9 (166). Chaperoning of CpG-ODN by extracellular GRP170 resulted in markedly increased internalization of $\mathrm{CpG}-\mathrm{ODN}$ by macrophages. The internalized GRP170 was seen to directly associate with endosomal TLR9, suggesting that GRP170 chaperoning may enhance the sensing of CpG-ODN by its receptor (i.e., TLR9). As a result, complexing of CpG-ODN with GRP170 leads to enhanced activation of the MyD88-dependent signaling cascade and production of pro-inflammatory cytokines for pathogen clearance (166). Indeed, GRP170-amplified innate immune response protected mice from challenge with Listeria monocytogenes (166). These results revealed a previously unrecognized attribute of GRP170 as a superior DNA-binding chaperone. More importantly, the interaction of an evolutionarily conserved chaperone molecule with PAMPs in the extracellular milieu may play a critical role in the host response to pathogen. Interestingly, other than internalized GRP170, TLR9 was associated with major endogenous GRPs, including GRP170, GRP94, and GRP78 (166), suggesting that the outside-in GRP170 may function in concert with intracellular chaperone networks in modifying TLR9 signaling. This result, together with a recent work showing a critical requirement of the chaperoning of TLR9 by intracellular GRP94 for TLR9 functions (167), offers new insight into the dynamics of ancient chaperoning functions inside and outside the cell. Given that CpG-ODN can be used as an immunostimulatory adjuvant in cancer vaccination (168), the unique characteristics of GRP170 in amplifying CpGODN-induced immune activation provide a scientific rationale for including the CpG-ODN as a component in the recombinant GRP170 vaccine regimen for cancer immunotherapy.

Among all the biological and immunological activities of extracellular GRP170, e.g., enhanced endocytosis of protein antigen or CpG-ODN, increased ER access of protein antigen, increased association with TLR9, all these processes seem to intimately involve the intrinsic chaperoning property of GRP170. During investigation of vaccine potential of various deletion mutant of GRP170 (37), we found that only chaperoning competent mutants exhibited APC binding activities and could deliver tumor antigen (e.g., gp100) for inducing an antigen-specific anti-tumor immunity (132). Interestingly, two of chaperoning competent GRP170 mutants, although both contained no overlapping sequences, could still bind to APCs in a receptor-mediated fashion and stimulate tumor-inhibiting CTL response. Together, these findings support the notion that the ancient chaperoning property is the key denominator underlying the diverse biological and immunological effects of GRP170 and possibly those other immunostimulatory GRPs (Figure 2).

\section{ARMING GRP170 WITH A PATHOGEN-DERIVED "DANGER" SIGNAL FOR IMPROVED ANTI-TUMOR POTENCY}

Coupling antigen and an immunostimulating "danger" signal into the same vaccine delivery cargo is crucial for optimal antigen cross-presentation by DCs and priming of antigen-reactive T cells $(169,170)$. While certain chaperone molecules in the extracellular environment, including GRP170, possess direct immunostimulatory activity during interaction with APCs, they do not activate an innate immune response as efficiently or robustly as PAMPs, which strongly promote a vaccine response $(171,172)$. The modest innate-stimulating effect of GRP170 may not be sufficient to fully activate antigen-exposed APCs in vivo. We hypothesized that incorporating a pathogen-derived "danger" signal into the GRP170 backbone would enhance its immunostimulatory potency in therapeutic immunization against cancer. To test this concept, we engineered a chimeric chaperone, termed Flagrp 170, by fusing GRP170 with the defined NF-кB-activating domain of Flagellin (173).

Flagellin is the principal substituent of bacterial flagella and the ligand for TLR5 (174-176). Since the NF- $\kappa$ B pathways in DCs are essential for its optimal functions $(169,177-179)$, this chimeric chaperone possesses two distinct features that are required for efficient cancer vaccine therapy: enhancing the cross-presentation of tumor antigens in the chaperone complex cargo and concurrently provoking the functional activation of DCs via engaging the NF- B signaling (173). As expected, Flagrp170 strongly activated DCs, indicated by elevation of co-stimulatory molecules, such as CD40 and CD86, as well as production of pro-inflammatory and Th1-polarizing cytokine IL-12. Since only a small portion of Flagellin was present in the construct, it was surprising that Flagrp170 exhibited a similar effect as Flagellin in stimulating NF-кB and MAPK signaling, as well as phenotypic activation of DCs. This might be due to the ability of GRP170 to amplify the innate immune response, as we observed in the study of GRP170 interaction with CpG-ODN (166). Moreover, Flagrp170 was much more efficacious than Flagellin in promoting antigen cross-presentation, which can be explained by the superior intrinsic property of GRP170 in antigen shuttling and T cell cross-priming (149).

Intratumoral delivery of Flagrp170 using an adenovirus induced a superior anti-tumor response against treated B16 melanoma and distant lung metastases compared with unmodified GRP170 or Flagellin treatment (173), which indicates systemic 


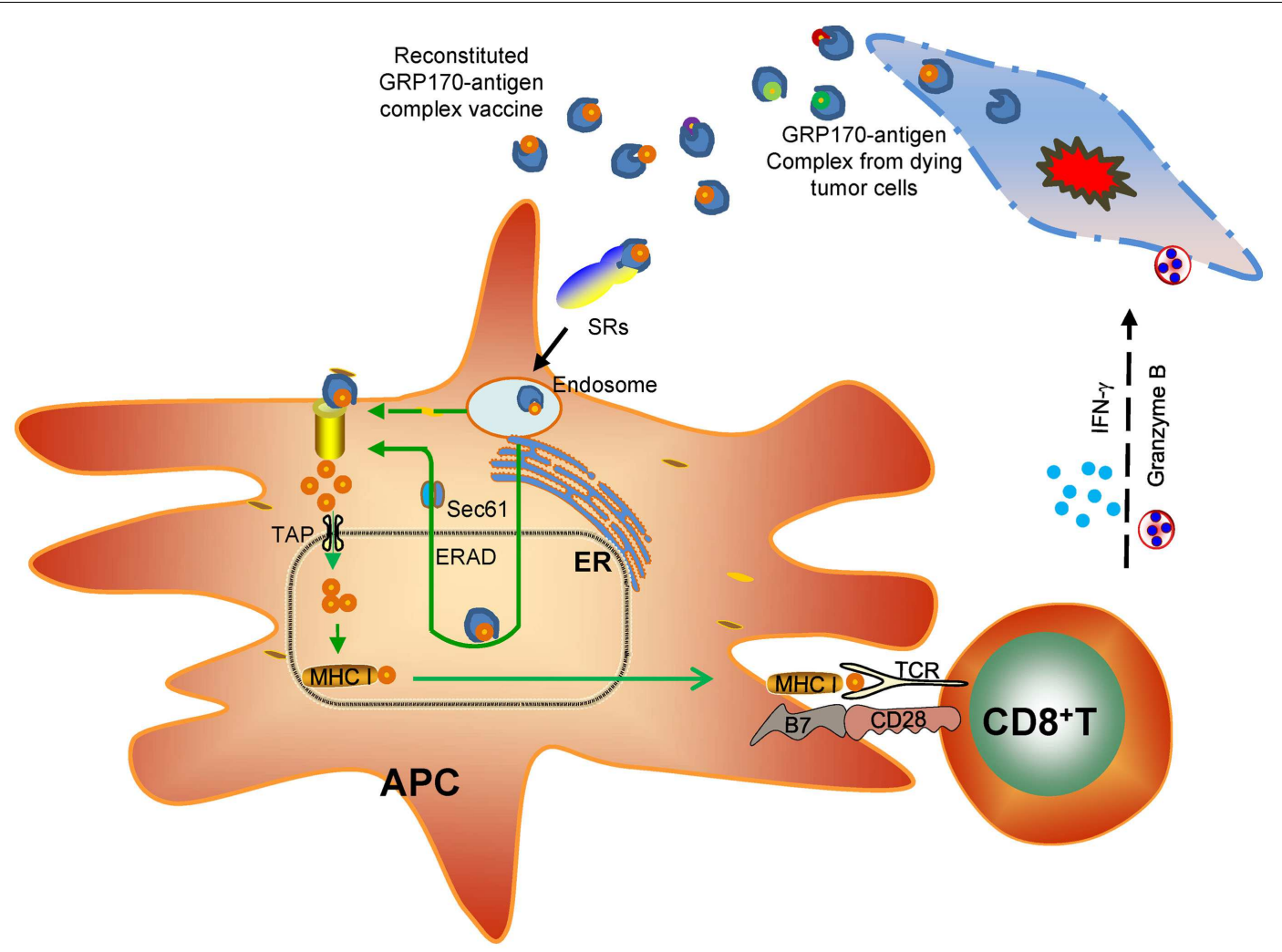

FIGURE 2 | Chaperoning-based immunological effects of extracellular GRP170 in cancer therapy. GRP170 isolated or released from cancer cells due to stress or injury is believed to chaperone tumor antigens. These tumor-derived GRP170-antigen complexes in the extracellular environment or reconstituted recombinant GRP170-antigen complex vaccine can be captured preferentially by specialized antigen-presenting cells (APCs) through the surface receptors (e.g., scavenger receptors, SRs). The GRP170 can direct the chaperone complexes to the endoplasmic reticulum (ER) and facilitate their interaction with the components of ER-associated degradation (ERAD) machinery (e.g., Sec61 $\alpha$ ). The antigen target will then be retrotranslocated to the cytosol for ubiquitination and proteasome-mediated processing. The generated antigenic peptides are transported by TAP and loaded on the MHC class I molecules. The MHC I-peptide cargo will traffick to the cell surface and prime $\mathrm{CD}^{+} \mathrm{T}$ cells. Activation and expansion of antigen-specific CD8 ${ }^{+} \mathrm{T}$ cells leads to eradication of antigen-positive tumor cells by releasing cytotoxic molecules (e.g., IFN- $\gamma$, granzyme B). mobilization of tumor-reactive immune effector cells. Flagrp170 treatment was shown to drive Th1 polarization of the tumor microenvironment, characterized by high levels of IL-12 and IFN$\gamma$, as well as tumor-infiltrating $\mathrm{CD}^{+}$and NK cells (173). Mechanistic studies showed that depletion of CD11c ${ }^{+}$cells or lack of $\mathrm{CD} 8 \alpha^{+}$DCs attenuated the anti-tumor response generated by Flagrp170 therapy, suggesting that Flagrp170-enhanced activation of tumor-specific CTLs depends on these DCs for efficient antigen cross-presentation (173). Interestingly, Flagrp170 selectively activated the NF- $\kappa \mathrm{B}$ signaling pathway in DCs, not in tumor cells, which suggests that Flagrp170 represents an ideal agent that may be exploited to condition the immunosuppressive tumor environment and to break immune tolerance established during tumor development or progression.

\section{CONCLUSION}

Glucose-regulated protein 170, as one of the largest GRPs and chaperone molecules in the ER, can protect cells during ER stresstriggered UPR and in other stressful and lethal conditions. The cytoprotective activity of GRP170 is also reflected in its elevation in certain cancer cells and resultant resistance of tumor cells to the induction of cell death, which supports a potential tumorpromoting role of GRP170 during cancer progression. While the intracellular chaperoning and NEF functions of GRP170 remain to be further defined, accumulating evidence has highlighted an immunoregulatory effect of GRP170 in the extracellular environment, indicated by its superior capacity in holding protein tumor antigens, facilitating antigen cross-presentation, enhancing $\mathrm{T}$ cell priming, and amplifying an innate immune response. These unique features have been exploited to develop GRP170 chaperone complex vaccine directed against defined antigenic target in cancers. The successful results derived from preclinical models have led to an ongoing phase I clinical trial of testing recombinant chaperone vaccine in melanoma patients. While this vaccine approach holds promise, more studies are needed to better understand the adjuvant action of GRP170 in therapeutic immunization. Studies are also needed with regard to the contributions of other DC subsets in GRP170-enhanced antigen cross-presentation, such as lymphoid organ resident $\mathrm{CD} 8 \alpha^{+} \mathrm{DCs}$ and dermal migratory CD103 ${ }^{+}$DCs (180-183). Recently, the role of the IRE $1 \alpha-X B P-1$ pathway has been extended beyond UPR and was shown to be required for the differentiation of effector 
$\mathrm{CD}^{+} \mathrm{T}$ cells and development or function of DCs (184-186). It is of interest to explore the potential involvement of GRP170 and other GRPs in this context because both intracellular and extracellular GRPs are likely to actively participate in these processes given their documented roles in antigen transportation, processing, and presentation. Integrating a NF- $\mathrm{KB}$-stimulating "danger" signal into the GRP170-based delivery cargo strongly enhances its immunostimulatory and anti-tumor efficacy, which warrants the future studies of Flagrp170 as a novel immunomodulating agent either alone or combined with conventional treatment modalities (chemotherapy and radiotherapy) to restore anti-tumor immunity in the tumor site to achieve in situ vaccination. It is also conceivable that this engineered GRP170 molecule can be used to design the new generation of targeted chaperone vaccine to deliver tumor protein antigens for the treatment of metastatic malignancies.

\section{ACKNOWLEDGMENTS}

The present study was supported in part by National Institutes of Health (NIH) Grants CA175033, CA154708, CA099326, Department of Defense (DOD) W81XWH-11-1-0481, and NCI Cancer Center Support Grant to VCU Massey Cancer Center P30CA16059. Xiang-Yang Wang is the Harrison Endowed Scholar in Cancer Research.

\section{REFERENCES}

1. Chen S, Novick P, Ferro-Novick S. ER structure and function. Curr Opin Cell Biol (2013) 25(4):428-33. doi:10.1016/j.ceb.2013.02.006

2. Araki K, Nagata K. Protein folding and quality control in the ER. Cold Spring Harb Perspect Biol (2011) 3(11):a007526. doi:10.1101/cshperspect.a007526

3. Gardner BM, Pincus D, Gotthardt K, Gallagher CM, Walter P. Endoplasmic reticulum stress sensing in the unfolded protein response. Cold Spring Harb Perspect Biol (2013) 5(3):a013169. doi:10.1101/cshperspect.a013169

4. Gidalevitz T, Stevens F, Argon Y. Orchestration of secretory protein folding by ER chaperones. Biochim Biophys Acta (2013) 1833(11):2410-24. doi:10.1016/ j.bbamcr.2013.03.007

5. Hartl FU, Bracher A, Hayer-Hartl M. Molecular chaperones in protein folding and proteostasis. Nature (2011) 475(7356):324-32. doi:10.1038/nature10317

6. Smith MH, Ploegh HL, Weissman JS. Road to ruin: targeting proteins for degradation in the endoplasmic reticulum. Science (2011) 334(6059):1086-90. doi:10.1126/science.1209235

7. Ron D, Walter P. Signal integration in the endoplasmic reticulum unfolded protein response. Nat Rev Mol Cell Biol (2007) 8(7):519-29. doi:10.1038/nrm2199

8. Li X, Zhang K, Li Z. Unfolded protein response in cancer: the physician's perspective. J Hematol Oncol (2011) 4:8. doi:10.1186/1756-8722-4-8

9. Rutkowski DT, Kaufman RJ. A trip to the ER: coping with stress. Trends Cell Biol (2004) 14(1):20-8. doi:10.1016/j.tcb.2003.11.001

10. Luo B, Lee AS. The critical roles of endoplasmic reticulum chaperones and unfolded protein response in tumorigenesis and anticancer therapies. Oncogene (2013) 32(7):805-18. doi:10.1038/onc.2012.130

11. Lee AS. The accumulation of three specific proteins related to glucose-regulated proteins in a temperature-sensitive hamster mutant cell line K12. J Cell Physiol (1981) 106(1):119-25. doi:10.1002/jcp.1041060113

12. Lee AS, Delegeane A, Scharff D. Highly conserved glucose-regulated protein in hamster and chicken cells: preliminary characterization of its cDNA clone. Proc Natl Acad Sci U S A (1981) 78(8):4922-5. doi:10.1073/pnas.78.8.4922

13. Sciandra JJ, Subjeck JR. The effects of glucose on protein synthesis and thermosensitivity in Chinese hamster ovary cells. J Biol Chem (1983) 258(20):12091-3.

14. Easton DP, Kaneko Y, Subjeck JR. The hsp110 and Grp1 70 stress proteins: newly recognized relatives of the Hsp70s. Cell Stress Chaperones (2000) 5(4):276-90. doi:10.1379/1466-1268(2000)005<0276:THAGSP > 2.0.CO;2

15. Lee AS. Glucose-regulated proteins in cancer: molecular mechanisms and therapeutic potential. Nat Rev Cancer (2014) 14(4):263-76. doi:10.1038/nrc3701
16. Wang XY, Subjeck JR. High molecular weight stress proteins: identification, cloning and utilisation in cancer immunotherapy. Int J Hyperthermia (2013) 29(5):364-75. doi:10.3109/02656736.2013.803607

17. Lee AS. The glucose-regulated proteins: stress induction and clinical applications. Trends Biochem Sci (2001) 26(8):504-10. doi:10.1016/S0968-0004(01) 01908-9

18. Wang M, Ye R, Barron E, Baumeister P, Mao C, Luo S, et al. Essential role of the unfolded protein response regulator GRP78/BiP in protection from neuronal apoptosis. Cell Death Differ (2010) 17(3):488-98. doi:10.1038/cdd.2009.144

19. Wey S, Luo B, Lee AS. Acute inducible ablation of GRP78 reveals its role in hematopoietic stem cell survival, lymphogenesis and regulation of stress signaling. PLoS One (2012) 7(6):e39047. doi:10.1371/journal.pone.0039047

20. Zhu G, Ye R, Jung DY, Barron E, Friedline RH, Benoit VM, et al. GRP78 plays an essential role in adipogenesis and postnatal growth in mice. FASEB J (2013) 27(3):955-64. doi:10.1096/fj.12-213330

21. Luo S, Mao C, Lee B, Lee AS. GRP78/BiP is required for cell proliferation and protecting the inner cell mass from apoptosis during early mouse embryonic development. Mol Cell Biol (2006) 26(15):5688-97. doi:10.1128/MCB. 00779-06

22. Calderwood SK, Khaleque MA, Sawyer DB, Ciocca DR. Heat shock proteins in cancer: chaperones of tumorigenesis. Trends Biochem Sci (2006) 31(3):164-72. doi:10.1016/j.tibs.2006.01.006

23. Calderwood SK, Ciocca DR. Heat shock proteins: stress proteins with Januslike properties in cancer. Int J Hyperthermia (2008) 24(1):31-9. doi:10.1080/ 02656730701858305

24. Srivastava PK, Menoret A, Basu S, Binder RJ, McQuade KL. Heat shock proteins come of age: primitive functions acquire new roles in an adaptive world. Immunity (1998) 8(6):657-65. doi:10.1016/S1074-7613(00)80570-1

25. Srivastava P. Interaction of heat shock proteins with peptides and antigen presenting cells: chaperoning of the innate and adaptive immune responses. Annu Rev Immunol (2002) 20:395-425. doi:10.1146/annurev.immunol.20.100301. 064801

26. Wang X-Y, Easton DP, Subjeck JR. The large mammalian hsp70 family proteins, hsp110 and grp170, and their roles in biology and cancer therapy. In: Calderwood SK, editor. Protein Reviews: Cell Stress Proteins, Vol 7. New York: Springer (2007). p. 178-205. doi:10.1007/978-0-387-39717-7_8

27. Chen X, Easton D, Oh HJ, LeeYoon DS, Liu XG, Subjeck J. The $170 \mathrm{kDa}$ glucose regulated stress protein is a large HSP70-, HSP110-like protein of the endoplasmic reticulum. FEBS Lett (1996) 380(1-2):68-72. doi:10.1016/0014-5793(96) 00011-7

28. Ikeda J, Kaneda S, Kuwabara K, Ogawa S, Kobayashi T, Matsumoto M, et al. Cloning and expression of cDNA encoding the human $150 \mathrm{kDa}$ oxygenregulated protein, ORP150. Biochem Biophys Res Commun (1997) 230(1):94-9. doi:10.1006/bbrc. 1996.5890

29. Craven RA, Tyson JR, Colin J, Stirling CJ. A novel subfamily of Hsp70s in the endoplasmic reticulum. Trends Cell Biol (1997) 7(7):277-82. doi:10.1016/ S0962-8924(97)01079-9

30. Gao YY, Liu BQ, Du ZX, Zhang HY, Niu XF, Wang HQ. Implication of oxygenregulated protein 150 (ORP150) in apoptosis induced by proteasome inhibitors in human thyroid cancer cells. JClin Endocrinol Metab (2010) 95(11):E319-26. doi:10.1210/jc.2010-1043

31. Namba T, Hoshino T, Tanaka K, Tsutsumi S, Ishihara T, Mima S, et al. Upregulation of $150-\mathrm{kDa}$ oxygen-regulated protein by celecoxib in human gastric carcinoma cells. Mol Pharmacol (2007) 71(3):860-70. doi:10.1124/mol.106. 027698

32. Sciandra JJ, Subjeck JR, Hughes CS. Induction of glucose-regulated proteins during anaerobic exposure and of heat-shock proteins after reoxygenation. Proc Natl Acad Sci U S A (1984) 81(15):4843-7. doi:10.1073/pnas.81.15.4843

33. Cai JW, Henderson BW, Shen JW, Subjeck JR. Induction of glucose regulated proteins during growth of a murine tumor. J Cell Physiol (1993) 154(2):229-37. doi:10.1002/jcp.1041540204

34. Whelan SA, Hightower LE. Differential induction of glucose-regulated and heat shock proteins: effects of $\mathrm{pH}$ and sulfhydryl-reducing agents on chicken embryo cells. J Cell Physiol (1985) 125(2):251-8. doi:10.1002/jcp.1041250212

35. Kuwabara K, Matsumoto M, Ikeda J, Hori O, Ogawa S, Maeda Y, et al. Purification and characterization of a novel stress protein, the $150-\mathrm{kDa}$ oxygenregulated protein (ORP150), from cultured rat astrocytes and its expression in ischemic mouse brain. J Biol Chem (1996) 271(9):5025-32. doi:10.1074/jbc. 271.9.5025 
36. Shen J, Hughes C, Chao C, Cai J, Bartels C, Gessner T, et al. Coinduction of glucose-regulated proteins and doxorubicin resistance in Chinese hamster cells. Proc Natl Acad Sci U S A (1987) 84(10):3278-82. doi:10.1073/pnas. 84.10.3278

37. Park J, Easton DP, Chen X, MacDonald IJ, Wang XY, Subjeck JR. The chaperoning properties of mouse grp170, a member of the third family of hsp70 related proteins. Biochemistry (2003) 42(50):14893-902. doi:10.1021/bi030122e

38. Shaner L, Morano KA. All in the family: atypical Hsp70 chaperones are conserved modulators of Hsp70 activity. Cell Stress Chaperones (2007) 12(1):1-8. doi:10.1379/CSC-245R.1

39. Lin HY, Masso-Welch P, Di YP, Cai JW, Shen JW, Subjeck JR. The 170-kDa glucose-regulated stress protein is an endoplasmic reticulum protein that binds immunoglobulin. Mol Biol Cell (1993) 4(11):1109-19. doi:10.1091/mbc. 4.11.1109

40. Melnick J, Dul JL, Argon Y. Sequential interaction of the chaperones BiP and GRP94 with immunoglobulin chains in the endoplasmic reticulum. Nature (1994) 370(6488):373-5. doi:10.1038/370373a0

41. Dierks T, Volkmer J, Schlenstedt G, Jung C, Sandholzer U, Zachmann K, et al. A microsomal ATP-binding protein involved in efficient protein transport into the mammalian endoplasmic reticulum. EMBO J (1996) 15(24):6931-42.

42. Spee P, Subjeck J, Neefjes J. Identification of novel peptide binding proteins in the endoplasmic reticulum: ERp72, calnexin, and grp170. Biochemistry (1999) 38(32):10559-66. doi:10.1021/bi990321r

43. Tyson JR, Stirling CJ. LHS1 and SIL1 provide a lumenal function that is essential for protein translocation into the endoplasmic reticulum. EMBO J (2000) 19(23):6440-52. doi:10.1093/emboj/19.23.6440

44. Craven RA, Egerton M, Stirling CJ. A novel Hsp70 of the yeast ER lumen is required for the efficient translocation of a number of protein precursors. EMBO J (1996) 15(11):2640-50.

45. Oh HJ, Chen X, Subjeck JR. Hsp110 protects heat-denatured proteins and confers cellular thermoresistance. J Biol Chem (1997) 272(50):31636-40. doi:10.1074/jbc.272.50.31636

46. Wang XY, Chen X, Manjili MH, Repasky E, Henderson R, Subjeck JR. Targeted immunotherapy using reconstituted chaperone complexes of heat shock protein 110 and melanoma-associated antigen gp100. Cancer Res (2003) 63(10):2553-60.

47. Wang XY, Arnouk H, Chen X, Kazim L, Repasky EA, Subjeck JR. Extracellular targeting of endoplasmic reticulum chaperone glucose-regulated protein 170 enhances tumor immunity to a poorly immunogenic melanoma. J Immunol (2006) 177(3):1543-51. doi:10.4049/jimmunol.177.3.1543

48. Wang XY, Sun X, Chen X, Facciponte J, Repasky EA, Kane J, et al. Superior antitumor response induced by large stress protein chaperoned protein antigen compared with peptide antigen. J Immunol (2010) 184(11):6309-19. doi:10.4049/jimmunol.0903891

49. Kampinga HH, Craig EA. The HSP70 chaperone machinery: J proteins as drivers of functional specificity. Nat Rev Mol Cell Biol (2010) 11(8):579-92. doi:10.1038/nrm2941

50. Andreasson C, Rampelt H, Fiaux J, Druffel-Augustin S, Bukau B. The endoplasmic reticulum Grp170 acts as a nucleotide exchange factor of Hsp70 via a mechanism similar to that of the cytosolic Hsp110. J Biol Chem (2010) 285(16):12445-53. doi:10.1074/jbc.M109.096735

51. Weitzmann A, Volkmer J, Zimmermann R. The nucleotide exchange factor activity of Grp170 may explain the non-lethal phenotype of loss of Sill function in man and mouse. FEBS Lett (2006) 580(22):5237-40. doi:10.1016/j. febslet.2006.08.055

52. de Keyzer J, Steel GJ, Hale SJ, Humphries D, Stirling CJ. Nucleotide binding by Lhs1p is essential for its nucleotide exchange activity and for function in vivo. J Biol Chem (2009) 284(46):31564-71. doi:10.1074/jbc.M109.055160

53. Behnke J, Hendershot LM. The large Hsp70 Grp170 binds to unfolded protein substrates in vivo with a regulation distinct from conventional Hsp70s. J Biol Chem (2014) 289(5):2899-907. doi:10.1074/jbc.M113.507491

54. Mandal AK, Gibney PA, Nillegoda NB, Theodoraki MA, Caplan AJ, Morano KA. Hsp 110 chaperones control client fate determination in the hsp70-Hsp90 chaperone system. Mol Biol Cell (2010) 21(9):1439-48. doi:10.1091/mbc.E0909-0779

55. Hotamisligil GS. Endoplasmic reticulum stress and atherosclerosis. Nat Med (2010) 16(4):396-9. doi:10.1038/nm0410-396

56. Xu C, Bailly-Maitre B, Reed JC. Endoplasmic reticulum stress: cell life and death decisions. J Clin Invest (2005) 115(10):2656-64. doi:10.1172/JCI26373
57. Rutkowski DT, Hegde RS. Regulation of basal cellular physiology by the homeostatic unfolded protein response. J Cell Biol (2010) 189(5):783-94. doi:10.1083/jcb.201003138

58. Kusaczuk M, Cechowska-Pasko M. Molecular chaperone ORP150 in ER stress-related diseases. Curr Pharm Des (2013) 19(15):2807-18. doi:10.2174/ 1381612811319150016

59. Schroder M, Kaufman RJ. ER stress and the unfolded protein response. Mutat Res (2005) 569(1-2):29-63. doi:10.1016/j.mrfmmm.2004.06.056

60. Hetz C. The unfolded protein response: controlling cell fate decisions under ER stress and beyond. Nat Rev Mol Cell Biol (2012) 13(2):89-102. doi:10.1038/ nrm3270

61. Walter P, Ron D. The unfolded protein response: from stress pathway to homeostatic regulation. Science (2011) 334(6059):1081-6. doi:10.1126/science. 1209038

62. Kaneda S, Yura T, Yanagi H. Production of three distinct mRNAs of 150 $\mathrm{kDa}$ oxygen-regulated protein (ORP150) by alternative promoters: preferential induction of one species under stress conditions. J Biochem (2000) 128(3):529-38. doi:10.1093/oxfordjournals.jbchem.a022783

63. Yoshida H, Haze K, Yanagi H, Yura T, Mori K. Identification of the cis-acting endoplasmic reticulum stress response element responsible for transcriptional induction of mammalian glucose-regulated proteins. Involvement of basic leucine zipper transcription factors. J Biol Chem (1998) 273(50):33741-9. doi:10.1074/jbc.273.50.33741

64. Travers KJ, Patil CK, Wodicka L, Lockhart DJ, Weissman JS, Walter P. Functional and genomic analyses reveal an essential coordination between the unfolded protein response and ER-associated degradation. Cell (2000) 101(3):249-58. doi:10.1016/S0092-8674(00)80835-1

65. Han D, Lerner AG, Vande Walle L, Upton JP, Xu W, Hagen A, et al. IRE1alpha kinase activation modes control alternate endoribonuclease outputs to determine divergent cell fates. Cell (2009) 138(3):562-75. doi:10.1016/j.cell.2009. 07.017

66. Sanson M, Auge N, Vindis C, Muller C, Bando Y, Thiers JC, et al. Oxidized low-density lipoproteins trigger endoplasmic reticulum stress in vascular cells: prevention by oxygen-regulated protein 150 expression. Circ Res (2009) 104(3):328-36. doi:10.1161/CIRCRESAHA.108.183749

67. Sanson M, Ingueneau C, Vindis C, Thiers JC, Glock Y, Rousseau H, et al. Oxygen-regulated protein-150 prevents calcium homeostasis deregulation and apoptosis induced by oxidized LDL in vascular cells. Cell Death Differ (2008) 15(8):1255-65. doi:10.1038/cdd.2008.36

68. Kretowski R, Borzym-Kluczyk M, Cechowska-Pasko M. Hypoxia enhances the senescence effect of bortezomib - the proteasome inhibitor - on human skin fibroblasts. Biomed Res Int (2014) 2014:196249. doi:10.1155/2014/196249

69. Kitano H, Nishimura H, Tachibana H, Yoshikawa H, Matsuyama T. ORP150 ameliorates ischemia/reperfusion injury from middle cerebral artery occlusion in mouse brain. Brain Res (2004) 1015(1-2):122-8. doi:10.1016/j.brainres. 2004.04.058

70. Ozawa K, Kuwabara K, Tamatani M, Takatsuji K, Tsukamoto Y, Kaneda S, et al. 150-kDa oxygen-regulated protein (ORP150) suppresses hypoxia-induced apoptotic cell death. J Biol Chem (1999) 274(10):6397-404. doi:10.1074/jbc. 274.10.6397

71. Tamatani M, Matsuyama T, Yamaguchi A, Mitsuda N, Tsukamoto Y, Taniguchi $\mathrm{M}$, et al. ORP150 protects against hypoxia/ischemia-induced neuronal death. Nat Med (2001) 7(3):317-23. doi:10.1038/85463

72. Aleshin AN, Sawa Y, Kitagawa-Sakakida S, Bando Y, Ono M, Memon IA, et al. $150-\mathrm{kDa}$ oxygen-regulated protein attenuates myocardial ischemia-reperfusion injury in rat heart. J Mol Cell Cardiol (2005) 38(3):517-25. doi:10.1016/j.yjmcc. 2005.01.001

73. Kitao Y, Ozawa K, Miyazaki M, Tamatani M, Kobayashi T, Yanagi H, et al. Expression of the endoplasmic reticulum molecular chaperone (ORP150) rescues hippocampal neurons from glutamate toxicity. J Clin Invest (2001) 108(10):1439-50. doi:10.1172/JCI200112978

74. Wang $\mathrm{Y}$, Wu Z, Li D, Wang D, Wang X, Feng X, et al. Involvement of oxygen-regulated protein 150 in AMP-activated protein kinase-mediated alleviation of lipid-induced endoplasmic reticulum stress. J Biol Chem (2011) 286(13):11119-31. doi:10.1074/jbc.M110.203323

75. Ye Z, Wang N, Xia P, Wang E, Liao J, Guo Q. Parecoxib suppresses CHOP and Foxol nuclear translocation, but increases GRP78 levels in a rat model of focal ischemia. Neurochem Res (2013) 38(4):686-93. doi:10.1007/s11064-0120953-4 
76. Fu Y, Lee AS. Glucose regulated proteins in cancer progression, drug resistance and immunotherapy. Cancer Biol Ther (2006) 5(7):741-4. doi:10.4161/cbt.5. 7.2970

77. Feldman DE, Chauhan V, Koong AC. The unfolded protein response: a novel component of the hypoxic stress response in tumors. Mol Cancer Res (2005) 3(11):597-605. doi:10.1158/1541-7786.MCR-05-0221

78. Hetz C. The UPR as a survival factor of cancer cells: more than folding proteins? Leuk Res (2009) 33(7):880-2. doi:10.1016/j.leukres.2009.02.017

79. Koumenis C. ER stress, hypoxia tolerance and tumor progression. Curr Mol Med (2006) 6(1):55-69. doi:10.2174/156652406775574604

80. Jamora C, Dennert G, Lee AS. Inhibition of tumor progression by suppression of stress protein GRP78/BiP induction in fibrosarcoma B/C10ME. Proc Natl Acad Sci U S A (1996) 93(15):7690-4. doi:10.1073/pnas.93.15.7690

81. Chen CN, Chang CC, Su TE, Hsu WM, Jeng YM, Ho MC, et al. Identification of calreticulin as a prognosis marker and angiogenic regulator in human gastric cancer. Ann Surg Oncol (2009) 16(2):524-33. doi:10.1245/s10434-008-0243-1

82. Hori O, Ichinoda F, Yamaguchi A, Tamatani T, Taniguchi M, Koyama Y, et al. Role of Herp in the endoplasmic reticulum stress response. Genes Cells (2004) 9(5):457-69. doi:10.1111/j.1356-9597.2004.00735.x

83. Kim I, Xu W, Reed JC. Cell death and endoplasmic reticulum stress: disease relevance and therapeutic opportunities. Nat Rev (2008) 7(12):1013-30. doi:10.1038/nrd2755

84. Vitadello M, Penzo D, Petronilli V, Michieli G, Gomirato S, Menabo R, et al. Overexpression of the stress protein Grp94 reduces cardiomyocyte necrosis due to calcium overload and simulated ischemia. FASEB J (2003) 17(8):923-5. doi:10.1096/fj.02-0644fje

85. Daneshmand S, Quek ML, Lin E, Lee C, Cote RJ, Hawes D, et al. Glucoseregulated protein GRP78 is up-regulated in prostate cancer and correlates with recurrence and survival. Hum Pathol (2007) 38(10):1547-52. doi:10.1016/j. humpath.2007.03.014

86. Fernandez PM, Tabbara SO, Jacobs LK, Manning FC, Tsangaris TN, Schwartz AM, et al. Overexpression of the glucose-regulated stress gene GRP78 in malignant but not benign human breast lesions. Breast Cancer Res Treat (2000) 59(1):15-26. doi:10.1023/A:1006332011207

87. Lee E, Nichols P, Spicer D, Groshen S, Yu MC, Lee AS. GRP78 as a novel predictor of responsiveness to chemotherapy in breast cancer. Cancer Res (2006) 66(16):7849-53. doi:10.1158/0008-5472.CAN-06-1660

88. Pootrakul L, Datar RH, Shi SR, Cai J, Hawes D, Groshen SG, et al. Expression of stress response protein Grp78 is associated with the development of castration-resistant prostate cancer. Clin Cancer Res (2006) 12(20 Pt 1):5987-93. doi:10.1158/1078-0432.CCR-06-0133

89. Reddy RK, Lu J, Lee AS. The endoplasmic reticulum chaperone glycoprotein GRP94 with $\mathrm{Ca}(2+)$-binding and antiapoptotic properties is a novel proteolytic target of calpain during etoposide-induced apoptosis. J Biol Chem (1999) 274(40):28476-83. doi:10.1074/jbc.274.40.28476

90. Banerjea A, Ahmed S, Hands RE, Huang F, Han X, Shaw PM, et al. Colorectal cancers with microsatellite instability display mRNA expression signatures characteristic of increased immunogenicity. Mol Cancer (2004) 3:21. doi:10.1186/1476-4598-3-21

91. Kubota H, Suzuki T, Lu J, Takahashi S, Sugita K, Sekiya S, et al. Increased expression of GRP94 protein is associated with decreased sensitivity to Xrays in cervical cancer cell lines. Int J Radiat Biol (2005) 81(9):701-9. doi:10.1080/09553000500434727

92. Tsukamoto Y, Kuwabara K, Hirota S, Kawano K, Yoshikawa K, Ozawa K, et al. Expression of the 150-kd oxygen-regulated protein in human breast cancer. Lab Invest (1998) 78(6):699-706.

93. Stojadinovic A, Hooke JA, Shriver CD, Nissan A, Kovatich AJ, Kao TC, et al. HYOU1/Orp150 expression in breast cancer. Med Sci Monit (2007) 13(11):BR231-9.

94. Ozawa K, Tsukamoto Y, Hori O, Kitao Y, Yanagi H, Stern DM, et al. Regulation of tumor angiogenesis by oxygen-regulated protein 150, an inducible endoplasmic reticulum chaperone. Cancer Res (2001) 61(10):4206-13.

95. Miyagi T, Hori O, Koshida K, Egawa M, Kato H, Kitagawa Y, et al. Antitumor effect of reduction of $150-\mathrm{kDa}$ oxygen-regulated protein expression on human prostate cancer cells. Int J Urol (2002) 9(10):577-85. doi:10.1046/j.1442-2042. 2002.00519.x

96. Asahi H, Koshida K, Hori O, Ogawa S, Namiki M. Immunohistochemical detection of the $150-\mathrm{kDa}$ oxygen-regulated protein in bladder cancer. BJU Int (2002) 90(4):462-6. doi:10.1046/j.1464-410X.2002.02915.x
97. Mahadevan NR, Rodvold J, Sepulveda H, Rossi S, Drew AF, Zanetti M. Transmission of endoplasmic reticulum stress and pro-inflammation from tumor cells to myeloid cells. Proc Natl Acad Sci U S A (2011) 108(16):6561-6. doi:10.1073/pnas. 1008942108

98. Basu S, Binder RJ, Suto R, Anderson KM, Srivastava PK. Necrotic but not apoptotic cell death releases heat shock proteins, which deliver a partial maturation signal to dendritic cells and activate the NF-kappa B pathway. Int Immunol (2000) 12(11):1539-46. doi:10.1093/intimm/12.11.1539

99. Zhang Y, Liu R, Ni M, Gill P, Lee AS. Cell surface relocalization of the endoplasmic reticulum chaperone and unfolded protein response regulator GRP78/BiP. J Biol Chem (2010) 285(20):15065-75. doi:10.1074/jbc.M109.087445

100. Feng H, Zeng Y, Graner MW, Likhacheva A, Katsanis E. Exogenous stress proteins enhance the immunogenicity of apoptotic tumor cells and stimulate antitumor immunity. Blood (2003) 101(1):245-52. doi:10.1182/blood-200205- 1580

101. Mambula SS, Calderwood SK. Heat shock protein 70 is secreted from tumor cells by a nonclassical pathway involving lysosomal endosomes. J Immunol (2006) 177(11):7849-57. doi:10.4049/jimmunol.177.11.7849

102. Misra UK, Gonzalez-Gronow M, Gawdi G, Hart JP, Johnson CE, Pizzo SV. The role of Grp 78 in alpha 2-macroglobulin-induced signal transduction. Evidence from RNA interference that the low density lipoprotein receptor-related protein is associated with, but not necessary for, GRP 78-mediated signal transduction. J Biol Chem (2002) 277(44):42082-7. doi:10.1074/jbc.M206174200

103. Misra UK, Pizzo SV. Receptor-recognized alpha(2)-macroglobulin binds to cell surface-associated GRP78 and activates mTORC1 and mTORC2 signaling in prostate cancer cells. PLoS One (2012) 7(12):e51735. doi:10.1371/journal. pone.0051735

104. Zhang Y, Tseng CC, Tsai YL, Fu X, Schiff R, Lee AS. Cancer cells resistant to therapy promote cell surface relocalization of GRP78 which complexes with PI3K and enhances PI(3,4,5)P3 production. PLoS One (2013) 8(11):e80071. doi:10.1371/journal.pone.0080071

105. Liu R, Li X, Gao W, Zhou Y, Wey S, Mitra SK, et al. Monoclonal antibody against cell surface GRP78 as a novel agent in suppressing PI3K/AKT signaling, tumor growth, and metastasis. Clin Cancer Res (2013) 19(24):6802-11. doi:10.1158/1078-0432.CCR-13-1106

106. Tamura Y, Hirohashi Y, Kutomi G, Nakanishi K, Kamiguchi K, Torigoe T, et al. Tumor-produced secreted form of binding of immunoglobulin protein elicits antigen-specific tumor immunity. J Immunol (2011) 186(7):4325-30. doi:10.4049/jimmunol.1004048

107. Martins I, Kepp O, Galluzzi L, Senovilla L, Schlemmer F, Adjemian S, et al. Surface-exposed calreticulin in the interaction between dying cells and phagocytes. Ann N Y Acad Sci (2010) 1209:77-82. doi:10.1111/j.1749-6632.2010. 05740.x

108. Obeid M, Panaretakis T, Joza N, Tufi R, Tesniere A, van Endert P, et al. Calreticulin exposure is required for the immunogenicity of gamma-irradiation and UVC light-induced apoptosis. Cell Death Differ (2007) 14(10):1848-50. doi:10.1038/sj.cdd.4402201

109. Obeid M, Panaretakis T, Tesniere A, Joza N, Tufi R, Apetoh L, et al. Leveraging the immune system during chemotherapy: moving calreticulin to the cell surface converts apoptotic death from "silent" to immunogenic. Cancer Res (2007) 67(17):7941-4. doi:10.1158/0008-5472.CAN-07-1622

110. Gao P, Sun X, Chen X, Subjeck J, Wang XY. Secretion of stress protein grp170 promotes immune-mediated inhibition of murine prostate tumor. Cancer Immunol Immunother (2009) 58(8):1319-28. doi:10.1007/s00262-0080647-6

111. Arnouk H, Zynda ER, Wang XY, Hylander BL, Manjili MH, Repasky EA, et al. Tumour secreted grp170 chaperones full-length protein substrates and induces an adaptive anti-tumour immune response in vivo. Int J Hyperthermia (2010) 26(4):366-75. doi:10.3109/02656730903485910

112. Dai J, Liu B, Caudill MM, Zheng H, Qiao Y, Podack ER, et al. Cell surface expression of heat shock protein gp96 enhances cross-presentation of cellular antigens and the generation of tumor-specific T cell memory. Cancer Immun (2003) 3:1.

113. Yamazaki K, Nguyen T, Podack ER. Cutting edge: tumor secreted heat shock-fusion protein elicits CD8 cells for rejection. J Immunol (1999) 163(10):5178-82.

114. Strbo N, Oizumi S, Sotosek-Tokmadzic V, Podack ER. Perforin is required for innate and adaptive immunity induced by heat shock protein gp96. Immunity (2003) 18(3):381-90. doi:10.1016/S1074-7613(03)00056-6 
115. Oizumi S, Strbo N, Pahwa S, Deyev V, Podack ER. Molecular and cellular requirements for enhanced antigen cross-presentation to CD8 cytotoxic T lymphocytes. J Immunol (2007) 179(4):2310-7. doi:10.4049/jimmunol.179.4.2310

116. Dai J, Liu B, Ngoi SM, Sun S, Vella AT, Li Z. TLR4 hyperresponsiveness via cell surface expression of heat shock protein gp96 potentiates suppressive function of regulatory T cells. J Immunol (2007) 178(5):3219-25. doi:10.4049/jimmunol.178.5.3219

117. Liu B, Dai J, Zheng H, Stoilova D, Sun S, Li Z. Cell surface expression of an endoplasmic reticulum resident heat shock protein gp96 triggers MyD88dependent systemic autoimmune diseases. Proc Natl Acad Sci U S A (2003) 100(26):15824-9. doi:10.1073/pnas.2635458100

118. Calderwood SK, Theriault JR, Gong J. Message in a bottle: role of the 70-kDa heat shock protein family in anti-tumor immunity. Eur J Immunol (2005) 35(9):2518-27. doi:10.1002/eji.200535002

119. Schmitt E, Gehrmann M, Brunet M, Multhoff G, Garrido C. Intracellular and extracellular functions of heat shock proteins: repercussions in cancer therapy. J Leukoc Biol (2007) 81(1):15-27. doi:10.1189/jlb.0306167

120. Manjili MH, Park JE, Facciponte JG, Wang XY, Subjeck JR. Immunoadjuvant chaperone, GRP170, induces 'danger signals' upon interaction with dendritic cells. Immunol Cell Biol (2006) 84(2):203-8. doi:10.1111/j.1440-1711.2006. 01418.x

121. Gao P, Sun X, Chen X, Wang Y, Foster BA, Subjeck J, et al. Secretable chaperone Grp170 enhances therapeutic activity of a novel tumor suppressor, mda-7/IL24. Cancer Res (2008) 68(10):3890-8. doi:10.1158/0008-5472.CAN-08-0156

122. Nair S, Wearsch PA, Mitchell DA, Wassenberg JJ, Gilboa E, Nicchitta CV. Calreticulin displays in vivo peptide-binding activity and can elicit CTL responses against bound peptides. J Immunol (1999) 162(11):6426-32.

123. Arnold D, Faath S, Rammensee H, Schild H. Cross-priming of minor histocompatibility antigen-specific cytotoxic $\mathrm{T}$ cells upon immunization with the heat shock protein gp96. J Exp Med (1995) 182(3):885-9. doi:10.1084/jem. 182.3.885

124. Nieland TJ, Tan MC, Monne-van Muijen M, Koning F, Kruisbeek AM, van Bleek GM. Isolation of an immunodominant viral peptide that is endogenously bound to the stress protein GP96/GRP94. Proc Natl Acad Sci U S A (1996) 93(12):6135-9. doi:10.1073/pnas.93.12.6135

125. Rivoltini L, Castelli C, Carrabba M, Mazzaferro V, Pilla L, Huber V, et al. Human tumor-derived heat shock protein 96 mediates in vitro activation and in vivo expansion of melanoma- and colon carcinoma-specific T cells. J Immunol (2003) 171(7):3467-74. doi:10.4049/jimmunol.171.7.3467

126. Wang XY, Kazim L, Repasky EA, Subjeck JR. Immunization with tumorderived ER chaperone grp170 elicits tumor-specific CD8+ T-cell responses and reduces pulmonary metastatic disease. Int J Cancer (2003) 105(2):226-31. doi:10.1002/ijc. 11058

127. Srivastava PK, DeLeo AB, Old LJ. Tumor rejection antigens of chemically induced sarcomas of inbred mice. Proc Natl Acad Sci U S A (1986) 83(10):3407-11. doi:10.1073/pnas.83.10.3407

128. Tamura Y, Peng P, Liu K, Daou M, Srivastava PK. Immunotherapy of tumors with autologous tumor-derived heat shock protein preparations. Science (1997) 278(5335):117-20. doi:10.1126/science.278.5335.117

129. Wang XY, Kazim L, Repasky EA, Subjeck JR. Characterization of heat shock protein 110 and glucose-regulated protein 170 as cancer vaccines and the effect of fever-range hyperthermia on vaccine activity. J Immunol (2001) 166(1):490-7. doi:10.4049/jimmunol.166.1.490

130. Oki Y, Younes A. Heat shock protein-based cancer vaccines. Expert Rev Vaccines (2004) 3(4):403-11. doi:10.1586/14760584.3.4.403

131. Gordon NF, Clark BL. The challenges of bringing autologous HSP-based vaccines to commercial reality. Methods (2004) 32(1):63-9. doi:10.1016/S10462023(03)00188-9

132. Park JE, Facciponte J, Chen X, MacDonald I, Repasky EA, Manjili MH, et al. Chaperoning function of stress protein grp170, a member of the hsp70 superfamily, is responsible for its immunoadjuvant activity. Cancer Res (2006) 66(2):1161-8. doi:10.1158/0008-5472.CAN-05-2609

133. Huo W, Ye J, Liu R, Chen J, Li Q. Vaccination with a chaperone complex based on PSCA and GRP170 adjuvant enhances the CTL response and inhibits the tumor growth in mice. Vaccine (2010) 28(38):6333-7. doi:10.1016/j.vaccine. 2010.06.093

134. Yuan B, Xian R, Wu X, Jing J, Chen K, Liu G, et al. Endoplasmic reticulum chaperone glucose regulated protein 170 -Pokemon complexes elicit a robust antitumor immune response in vivo. Immunobiology (2012) 217(7):738-42. doi:10.1016/j.imbio.2012.01.006

135. Cresswell P, Ackerman AL, Giodini A, Peaper DR, Wearsch PA. Mechanisms of MHC class I-restricted antigen processing and cross-presentation. Immunol $\operatorname{Rev}(2005)$ 207:145-57. doi:10.1111/j.0105-2896.2005.00316.x

136. Joffre OP, Segura E, Savina A, Amigorena S. Cross-presentation by dendritic cells. Nat Rev Immunol (2012) 12:557-69. doi:10.1038/nri3254

137. Schuette V, Burgdorf S. The ins-and-outs of endosomal antigens for cross-presentation. Curr Opin Immunol (2014) 26:63-8. doi:10.1016/j.coi. 2013.11.001

138. Kovacsovics-Bankowski M, Rock KL. A phagosome-to-cytosol pathway for exogenous antigens presented on MHC class I molecules. Science (1995) 267(5195):243-6. doi:10.1126/science.7809629

139. Rodriguez A, Regnault A, Kleijmeer M, Ricciardi-Castagnoli P, Amigorena S. Selective transport of internalized antigens to the cytosol for MHC class I presentation in dendritic cells. Nat Cell Biol (1999) 1(6):362-8. doi:10.1038/14058

140. Di Pucchio T, Chatterjee B, Smed-Sorensen A, Clayton S, Palazzo A, Montes $\mathrm{M}$, et al. Direct proteasome-independent cross-presentation of viral antigen by plasmacytoid dendritic cells on major histocompatibility complex class I. Nat Immunol (2008) 9(5):551-7. doi:10.1038/ni.1602

141. Gromme M, Uytdehaag FG, Janssen H, Calafat J, van Binnendijk RS, Kenter MJ, et al. Recycling MHC class I molecules and endosomal peptide loading. Proc Natl Acad Sci U S A (1999) 96(18):10326-31. doi:10.1073/pnas.96.18.10326

142. Pfeifer JD, Wick MJ, Roberts RL, Findlay K, Normark SJ, Harding CV. Phagocytic processing of bacterial antigens for class I MHC presentation to T cells. Nature (1993) 361(6410):359-62. doi:10.1038/361359a0

143. Shen L, Sigal LJ, Boes M, Rock KL. Important role of cathepsin S in generating peptides for TAP-independent MHC class I crosspresentation in vivo. Immunity (2004) 21(2):155-65. doi:10.1016/j.immuni.2004.07.004

144. Srivastava P. Roles of heat-shock proteins in innate and adaptive immunity. Nat Rev Immunol (2002) 2(3):185-94. doi:10.1038/nri749

145. Srivastava PK, Callahan MK, Mauri MM. Treating human cancers with heat shock protein-peptide complexes: the road ahead. Expert Opin Biol Ther (2009) 9(2):179-86. doi:10.1517/14712590802633918

146. Wang XY, Facciponte JG, Subjeck JR. Molecular chaperones and cancer immunotherapy. Handb Exp Pharmacol (2006) 172(172):305-29. doi:10.1007/ 3-540-29717-0_13

147. Murshid A, Gong J, Calderwood SK. The role of heat shock proteins in antigen cross presentation. Front Immunol (2012) 3:63. doi:10.3389/fimmu.2012.00063

148. Facciponte JG, Wang XY, Subjeck JR. Hsp110 and Grp170, members of the Hsp70 superfamily, bind to scavenger receptor-A and scavenger receptor expressed by endothelial cells-I. Eur J Immunol (2007) 37(8):2268-79. doi:10.1002/eji.200737127

149. Wang H, Yu X, Guo C, Zuo D, Fisher PB, Subjeck JR, et al. Enhanced endoplasmic reticulum entry of tumor antigen is crucial for cross-presentation induced by dendritic cell-targeted vaccination. J Immunol (2013) 191(12):6010-21. doi:10.4049/jimmunol.1302312

150. Buck TM, Plavchak L, Roy A, Donnelly BF, Kashlan OB, Kleyman TR, et al. The Lhs1/GRP170 chaperones facilitate the endoplasmic reticulumassociated degradation of the epithelial sodium channel. J Biol Chem (2013) 288(25):18366-80. doi:10.1074/jbc.M113.469882

151. Kutomi G, Tamura Y, Okuya K, Yamamoto T, Hirohashi Y, Kamiguchi K, et al. Targeting to static endosome is required for efficient cross-presentation of endoplasmic reticulum-resident oxygen-regulated protein 150-peptide complexes. J Immunol (2009) 183(9):5861-9. doi:10.4049/jimmunol.0803768

152. Tsai B, Ye Y, Rapoport TA. Retro-translocation of proteins from the endoplasmic reticulum into the cytosol. Nat Rev Mol Cell Biol (2002) 3(4):246-55. doi: $10.1038 / \mathrm{nrm} 780$

153. Vembar SS, Brodsky JL. One step at a time: endoplasmic reticulum-associated degradation. Nat Rev Mol Cell Biol (2008) 9(12):944-57. doi:10.1038/nrm2546

154. Udono $H$. Heat shock protein magic in antigen trafficking within dendritic cells: implications in antigen cross-presentation in immunity. Acta Med Okayama (2012) 66(1):1-6.

155. Ackerman AL, Giodini A, Cresswell P. A role for the endoplasmic reticulum protein retrotranslocation machinery during crosspresentation by dendritic cells. Immunity (2006) 25(4):607-17. doi:10.1016/j.immuni.2006.08.017

156. Gagnon E, Duclos S, Rondeau C, Chevet E, Cameron PH, Steele-Mortimer O, et al. Endoplasmic reticulum-mediated phagocytosis is a mechanism of entry 
into macrophages. Cell (2002) 110(1):119-31. doi:10.1016/S0092-8674(02) 00797-3

157. Guermonprez P, Saveanu L, Kleijmeer M, Davoust J, Van Endert P, Amigorena S. ER-phagosome fusion defines an MHC class I cross-presentation compartment in dendritic cells. Nature (2003) 425(6956):397-402. doi:10.1038/nature01911

158. Houde M, Bertholet S, Gagnon E, Brunet S, Goyette G, Laplante A, et al. Phagosomes are competent organelles for antigen cross-presentation. Nature (2003) 425(6956):402-6. doi:10.1038/nature01912

159. Calderwood SK, Mambula SS, Gray PJ Jr. Extracellular heat shock proteins in cell signaling and immunity. Ann N Y Acad Sci (2007) 1113:28-39. doi:10.1196/annals.1391.019

160. Henderson B, Calderwood SK, Coates AR, Cohen I, van Eden W, Lehner T, et al. Caught with their PAMPs down? The extracellular signalling actions of molecular chaperones are not due to microbial contaminants. Cell Stress Chaperones (2010) 15(2):123-41. doi:10.1007/s12192-009-0137-6

161. Akira S. Innate immunity and adjuvants. Philos Trans R Soc Lond B Biol Sci (2011) 366(1579):2748-55. doi:10.1098/rstb.2011.0106

162. Coffman RL, Sher A, Seder RA. Vaccine adjuvants: putting innate immunity to work. Immunity (2010) 33(4):492-503. doi:10.1016/j.immuni.2010.10.002

163. Ghimire TR, Benson RA, Garside P, Brewer JM. Alum increases antigen uptake, reduces antigen degradation and sustains antigen presentation by DCs in vitro. Immunol Lett (2012) 147(1-2):55-62. doi:10.1016/j.imlet.2012.06.002

164. Huang M, Wang W. Factors affecting alum-protein interactions. Int J Pharm (2014) 466(1-2):139-46. doi:10.1016/j.ijpharm.2014.03.015

165. Colaco CA, Bailey CR, Walker KB, Keeble J. Heat shock proteins: stimulators of innate and acquired immunity. Biomed Res Int (2013) 2013:461230. doi:10.1155/2013/461230

166. Zuo D, Yu X, Guo C, Yi H, Chen X, Conrad DH, et al. Molecular chaperoning by glucose-regulated protein 170 in the extracellular milieu promotes macrophage-mediated pathogen sensing and innate immunity. FASEB J (2012) 26(4):1493-505. doi:10.1096/fj.11-197707

167. Yang Y, Liu B, Dai J, Srivastava PK, Zammit DJ, Lefrancois L, et al. Heat shock protein gp96 is a master chaperone for toll-like receptors and is important in the innate function of macrophages. Immunity (2007) 26(2):215-26. doi:10.1016/j.immuni.2006.12.005

168. Speiser DE, Lienard D, Rufer N, Rubio-Godoy V, Rimoldi D, Lejeune F, et al. Rapid and strong human CD8+ T cell responses to vaccination with peptide, IFA, and CpG oligodeoxynucleotide 7909. J Clin Invest (2005) 115(3):739-46. doi:10.1172/JCI200523373

169. Andreakos E, Williams RO, Wales J, Foxwell BM, Feldmann M. Activation of NF-kappaB by the intracellular expression of NF-kappaB-inducing kinase acts as a powerful vaccine adjuvant. Proc Natl Acad Sci U S A (2006) 103(39):14459-64. doi:10.1073/pnas.0603493103

170. Blander JM, Medzhitov R. Toll-dependent selection of microbial antigens for presentation by dendritic cells. Nature (2006) 440(7085):808-12. doi:10.1038/ nature 04596

171. Akira S, Takeda K. Toll-like receptor signalling. Nat Rev Immunol (2004) 4:499-511. doi:10.1038/nri1391

172. van Duin D, Medzhitov R, Shaw AC. Triggering TLR signaling in vaccination. Trends Immunol (2006) 27(1):49-55. doi:10.1016/j.it.2005.11.005

173. Yu X, Guo C, Yi H, Qian J, Fisher PB, Subjeck JR, et al. A multifunctional chimeric chaperone serves as a novel immune modulator inducing therapeutic antitumor immunity. Cancer Res (2013) 73(7):2093-103. doi:10.1158/00085472.CAN-12-1740

174. Murthy KG, Deb A, Goonesekera S, Szabo C, Salzman AL. Identification of conserved domains in Salmonella muenchen flagellin that are essential for its ability to activate TLR5 and to induce an inflammatory response in vitro. J Biol Chem (2004) 279(7):5667-75. doi:10.1074/jbc.M307759200

175. Hayashi F, Smith KD, Ozinsky A, Hawn TR, Yi EC, Goodlett DR, et al. The innate immune response to bacterial flagellin is mediated by toll-like receptor 5. Nature (2001) 410(6832):1099-103. doi:10.1038/35074106
176. Yoon SI, Kurnasov O, Natarajan V, Hong M, Gudkov AV, Osterman AL, et al. Structural basis of TLR5-flagellin recognition and signaling. Science (2012) 335(6070):859-64. doi:10.1126/science.1215584

177. Yoshimura S, Bondeson J, Foxwell BMJ, Brennan FM, Feldmann M. Effective antigen presentation by dendritic cells is NF- $\{\{$ kappa $\}\} B$ dependent: coordinate regulation of $\mathrm{MHC}$, co-stimulatory molecules and cytokines. Int Immunol (2001) 13(5):675-83. doi:10.1093/intimm/13.5.675

178. Moore F, Buonocore S, Aksoy E, Ouled-Haddou N, Goriely S, Lazarova E, et al. An alternative pathway of NF-\{kappa\}B activation results in maturation and $\mathrm{T}$ cell priming activity of dendritic cells overexpressing a mutated I $\{$ kappa\}B\{alpha\}. J Immunol (2007) 178(3):1301-11. doi:10.4049/jimmunol. 178.3.1301

179. Lind EF, Ahonen CL, Wasiuk A, Kosaka Y, Becher B, Bennett KA, et al. Dendritic Cells require the NF-\{kappa\}B2 pathway for cross-presentation of soluble antigens. JImmunol (2008) 181(1):354-63. doi:10.4049/jimmunol.181. 1.354

180. Bedoui S, Whitney PG, Waithman J, Eidsmo L, Wakim L, Caminschi I, et al. Cross-presentation of viral and self antigens by skin-derived CD103+ dendritic cells. Nat Immunol (2009) 10(5):488-95. doi:10.1038/ni.1724

181. Heath WR, Belz GT, Behrens GM, Smith CM, Forehan SP, Parish IA, et al. Cross-presentation, dendritic cell subsets, and the generation of immunity to cellular antigens. Immunol Rev (2004) 199:9-26. doi:10.1111/j.0105-2896. 2004.00142.x

182. Henri S, Siret C, Machy P, Kissenpfennig A, Malissen B, Leserman L. Mature DC from skin and skin-draining LN retain the ability to acquire and efficiently present targeted antigen. Eur J Immunol (2007) 37(5):1184-93. doi:10.1002/ eji.200636793

183. Hildner K, Edelson BT, Purtha WE, Diamond M, Matsushita H, Kohyama M, et al. Batf3 deficiency reveals a critical role for CD8alpha+ dendritic cells in cytotoxic T cell immunity. Science (2008) 322(5904):1097-100. doi:10.1126/ science. 1164206

184. Osorio F, Tavernier SJ, Hoffmann E, Saeys Y, Martens L, Vetters J, et al. The unfolded-protein-response sensor IRE-1alpha regulates the function of CD8alpha+ dendritic cells. Nat Immunol (2014) 15(3):248-57. doi:10.1038/ ni. 2808

185. Iwakoshi NN, Pypaert M, Glimcher LH. The transcription factor XBP-1 is essential for the development and survival of dendritic cells. J Exp Med (2007) 204(10):2267-75. doi:10.1084/jem.20070525

186. Kamimura D, Bevan MJ. Endoplasmic reticulum stress regulator XBP-1 contributes to effector CD8+ T cell differentiation during acute infection. J Immunol (2008) 181(8):5433-41. doi:10.4049/jimmunol.181.8.5433

Conflict of Interest Statement: The authors declare that the research was conducted in the absence of any commercial or financial relationships that could be construed as a potential conflict of interest.

Received: 31 October 2014; paper pending published: 26 November 2014; accepted: 16 December 2014; published online: 12 January 2015.

Citation: Wang H, Pezeshki AM, Yu X, Guo C, Subjeck JR and Wang X-Y (2015) The endoplasmic reticulum chaperone GRP170: from immunobiology to cancer therapeutics. Front. Oncol. 4:377. doi: 10.3389/fonc.2014.00377

This article was submitted to Tumor Immunity, a section of the journal Frontiers in Oncology.

Copyright (C) 2015 Wang, Pezeshki, Yu, Guo, Subjeck and Wang. This is an openaccess article distributed under the terms of the Creative Commons Attribution License (CC BY). The use, distribution or reproduction in other forums is permitted, provided the original author(s) or licensor are credited and that the original publication in this journal is cited, in accordance with accepted academic practice. No use, distribution or reproduction is permitted which does not comply with these terms. 